\title{
婯 McGill
}

Ignasi Marti, Dror Etzion, and Bernard Leca

Theoretical Approaches for Studying Corporations, Democracy, and the Public Good

Journal of Management Inquiry September 2008 vol. 17 no. 3 148-

151

doi: $10.1177 / 1056492608318147$

http://jmi.sagepub.com/content/17/3/148

Uploaded to eScholarship@McGill.ca on 23 October 2015. All items in eScholarship@McGill.ca are protected by copyright with all rights reserved unless otherwise indicated. 


\author{
Ignasi Martí \\ EM Lyon \\ 23 Avenue de Collongue \\ 69130 Ecully, France \\ marti@em-lyon.com \\ Dror Etzion \\ IESE Business School \\ Avda. Pearson 21 \\ Barcelona, Spain, 08034 \\ docdetzion@iese.edu \\ Bernard Leca \\ Groupe ESC Rouen \\ 1, rue du Maréchal Juin - BP 215 \\ 76825 Mont Saint Aignan Cedex, France \\ bernard.leca@groupe-esc-rouen.fr
}

\begin{abstract}
Answering Stephen Barley's call for academic research on the role of corporations in democratic societies, we convened a Professional Development Workshop at the 2007 Academy of Management annual meeting in Philadelphia. The ideas presented in this workshop are summarized in the following articles. In this introduction, we review some key points from the presentations delivered and highlight some theoretical orientations and questions that can guide future empirical analysis in this important and exciting domain.
\end{abstract}


At a time when organizations seem to have become "the only kind of actor with significant cultural and political influence” (Stern and Barley, 1996: 148), the ways organizations interact with and exert influence upon executive, legislative and judiciary branches of governments and multilateral global organizations can no longer be ignored. We believe it should occupy a central place in organizational research.

Stephen Barley’s OMT Distinguished Scholar Lecture in the Academy of Management Meeting in Atlanta in 2006 - recently published in the Journal of Management Inquiry (Barley, 2007) - is at the vanguard of a movement towards reorienting research from how environments affect organizations to how organizations affect their environments; and more specifically, to how they impact democracy and possibly redefine the notion of public good. Echoing this concern and sharing the view that organizational researchers must do more work on this topic, an ensemble of leading scholars agreed to join a Professional Development Workshop (PDW) at the 2007 Academy meeting in Philadelphia to reflect and elaborate on Barley’s call for action, and to identify directions for further research. The texts that follow are based on their presentations in this PDW.

\section{Scope of potential research - components of a manifesto}

Barley, commenting on his lecture in Atlanta, indicated that "The talk represents my first attempt to speak about a growing concern of mine: the role of the corporation in 
contemporary American democracy and my fears for our country’s future as a republic” (Marquis \& Barley, 2006).

Indeed most current organizational research falls short of addressing the negative - either intended or unintended - consequences of corporate activities (Hinings \& Greenwood, 2002). Investigating the relationship between corporations and a properly functioning and vibrant democracy opens wide avenues for research. While much has been written about corporate scandals and managerial shenanigans, we believe that focusing our attention on debacles not only misses the mark, but also serves to misdirect attention to specific instances of excess, rather than on the systemic foundations that foster these lapses. Paraphrasing Perrow (1984), recurrent corporate meltdowns may be no more than "normal accidents" in societies where corporate interests wield a remarkable amount of freedom and resources to pursue all kind of activities that are often perfectly legitimized and taken for granted, albeit not always transparent and visible. Put differently - solid, respectable companies use money, influence, lawyers, lobbyists, PR specialists, communications experts and many other tools to influence the democracies and societies we live in. Usually, all this is perfectly legal. Usually, it is also well below the radar, and is simply unnoticed. This is where we see fodder for research.

If we assume that a key characteristic of democracy is, as Robert Dahl puts it, "the continuous responsiveness of the government to the preferences of its citizens, considered as political equals” (1971: 1), it is readily observable that the fundamental problem here is that some citizens are less equal than others. Financial resources, strategic skills, expertise in dealing with government actors and the judiciary are just some of the elements of the diverse and rich toolkit that corporations utilize, on a playing 
field originally designed for natural persons, and not “corporate citizens”. We believe that research should not focus -at least not exclusively- on what those resources, strategies and skills are. This has been extensively studied by corporate political researchers (see Schuler, 2008). What needs to be addresed is how these corporate strategies affect the quality of domocratic institutions and regimes, as well as how other actors respond to them.

Yet, while we advocate an unbiased and thus less managerialist analysis of corporate political activities, we are wary of venturing too far into radical critiques of capitalism and of the impact of corporations' actions on democracy. We aspire to a firmly grounded empirical approach, emphasizing problem-driven research as opposed to epic theorizing (Davis \& Marquis, 2005). While cognizant that science is never devoid of normative bias, we believe that our research outputs will carry more weight and be more useful for academic audiences, policymakers and business practitioners if we focus on the facts, and piece them together into cohesive portrayals of the relation between companies and democratic institutions.

We emphasize that what we see as pertinent is the relationship between corporations and democracy and not the relationship between corporations and wealth creation. Some scholars see an implicit relationship between the development of free markets and democracy, a view made explicit by Fukuyama (1992). In this paradigm, the development of free markets and creation of wealth are considered as positive for democracy (see for example Bernstein and Berger, 2000). Yet, recent history in countries such as Russia and China suggests that the positive correlation between free markets, creation of wealth and the development of democracy is not very clear. Research that 
utilizes dependent variables other than the ubiquitous financial performance (Walsh, Weber \& Margolis 2003) can help untangle these interdependencies.

Similarly, an increasing number of researchers are focusing their attention on the role of large MNCs, conglomerates, and business groups in emerging countries or economies in transition. Many of these studies emphasize the capacity of these organizations to adapt to and shape their environment, and much of this research has centred on how corporations are in fact viable alternatives for socio-political institutions. However, while these studies dwell on, and emphasize, the economic efficiency that results from such substitutions (e.g. Khanna, 2000; Khanna \& Yafeh, 2007), little thought has been given to the extent to which corporate activities may slow or even impede the further development and strengthening of nascent democratic regimes in these countries. In sum, we perceive the corpus of research on the corporate-government interface - both in the context of developed countries and developing countries - as insufficient, and perhaps dangerously shortsighted.

\section{Three theoretical approaches}

Several influential scholars (e.g. Hinings \& Greenwood, 2002; Perrow, 1986, 2002; Stern \& Barley, 1996), remind us that organization theorists have not paid heed to the impact of corporations on democracy. Yet, clarion calls for further research have so far been, by and large, ignored. We believe organizational researchers can be instrumental in providing important insights on these issues due to their expert knowledge of organizations and organizing, grounded in empirical research. The three 
short essays that follow this introduction, in addition to the rejoinder by Barley, are part of an effort to mainstream research on corporations, democracy and the public good. We believe they are a good first step for reigniting academic interest on the influence of business on society, and hope they will serve to whet the appetites of our colleagues as they formulate and reformulate their research agendas.

Royston Greenwood (2008) in "Focusing the Asteroid Belt of Organizations” provides guidance on how we can use the main tools developed in organizational institutionalism to better understand corporations’ activities and effects. Specifically, Greenwood focuses on (1) legitimacy, and the linguistic devices that cloak clearly political interests; and (2) the clash between different institutional logics. From a methodological standpoint he recommends the organizational field as a key level of analysis. Finally, in an interesting extension of Barley’s focus on corporate actors 'per se’, Greenwood emphasizes studying 'referees' such as the SEC, FDA, audit firms and law firms.

Dror Etzion and Gerald Davis (2008), in “Revolving Doors? A Network Analysis of Corporate Officers and U.S. Government Officials”, echo Mills’ (1956) penetrating analysis of the organization of power in the United States in the 1950s. Using social network analysis, they show, in detail, the movement of business elites into and out of the US executive branch in the Clinton and George W. Bush ad ministrations. Where other studies have demonstrated the ways and means by which corporations use money, information and votes as tools to influence government, Etzion and Davis encourage us to view the worlds of business and government as interwoven, with bi-directional flows of 
persons, and hence ideas, networks, mindsets and interests between these two ostensibly distinct elements of society.

Finally, Douglas Schuler (2008), in “Peering in From Corporate Political Activity”, offers a review of how the literature on corporate political activity aligns and also can contribute to extend and complement some of the points raised by Barley (2007). Schuler illustrates how existing research has mostly centered on understanding the antecedents that explain interests of business influencing public policy, the different types or forms that such influence takes (lobbying, campaigns, buffering, bridging, etc.) and the outcomes of such efforts. However, as for the latter, he shows how most research has largely abandoned concerns about the public economic, social, and political outcomes arising from corporate political activity. Notwithstanding, Schuler argues that Barley’s analysis underestimates some of the countervailing forces against dominance of corporate interests in public policy since, for example non-business interest groups. Thus, Schuler argues, the study of how corporations affect democratic institutions and the public good is necessarily complex and multilayered.

\section{Other theoretical frameworks}

We believe that the ideas and challenges raised by the articles in this section and in Barley’s (2007) germinal paper clearly indicate that the study of these and related issues offer a fertile area for scholarly research on organizations. Some other theoretical frameworks are worth mentioning in this context. 
Research integrating organization theory and social movements (e.g. Davis, McAdam, Scott, \& Zald, 2005; Lounsbury, Ventresca \& Hirsch, 2003; Schneiberg \& Bartley, 2001) can clearly be used to develop a richer understanding of the interactions between various organizational archetypes and democracy, broadly conceptualized. For example, in studying the convergence of rate regulation in American fire insurance throughout the United States, Schneiberg and Soule (2004) demonstrate that the process is a contested one in which social movements oppose corporate interests. This nuanced analysis suggests that organizational theorists might study legislation as a complex process where multiple actors - neither only corporations, nor only social movements interact and jostle in providing alternative manifestations of capitalism (see also Schneiberg and Lounsbury, forthcoming).

Critical management scholars also argue that we should pay more attention to corporations, democracy and public good and offer interesting approaches to analyze those complex interactions. Clegg (2002) and Perrow (2002) have made important contributions as have Levy and colleagues (e.g. Levy and Egan, 2003; Levy and Newell, 2002), in employing the notion of hegemony in a neo-Gramscian perspective. What these bodies of work have in common is that they emphasize how corporations shape the world we live in in many different ways and at different levels. They remind us is that large corporations are oftentimes oversized citizens, setting not only economic rules, but also political ones.

In addition, researchers can draw from a long and rich tradition in sociology, political science (e.g. Lindblom, 1977; Mills, 1956; Mintz \& Schwartz, 1985; Mizruchi, 1992; Useem, 1984), business history (Adams, 1997; Lipartito \& Sicilia, 2004), as well 
as an increasing number of economists (eg., Reich, 2007) of studying how corporate actors and networks connect to political power and their power over other interests. Indeed, the study of corporate effects on democratic institutions and the public good seems to have been largely abandoned -with some remarkable exceptions such as the studies just mentioned- rather than never having commenced. Existing work as well as the more contemporary approaches exemplified by the papers collected here can provide researchers with much theoretical material and methodological tools for further investigation. 
Studying Corporations, Democracy and the Public Good

\section{References}

Adams, S. B. (1997). Mr. Kaiser Goes to Washington: The Rise of a Government Entrepreneur. Chapel Hill: The University of North Carolina Press.

Barley, S. R. (2007). “Corporations, Democracy, and the Public Good” Journal of Management Inquiry, 16(3), 201-215.

Bernstein, A. \& Berger, P. L. (Eds.). (2000) Business and Democracy, Cohabitation or Contradiction? London: Continuum.

Clegg, S. R. (2002). '"Lives in the Balance": A Comment on Professors Hinings and Greenwood’s "Disconnects and Consequences in Organization Theory?”. Administrative Science Quarterly, 47(3), 428-441.

Dahl, R. A. (1971). Polyarchy. Participation and opposition. New Haven: Yale University Press,

Davis, G. F., \& Marquis, C. (2005). Prospects for Organization Theory in the Early Twenty-First Century: Institutional Fields and Mechanisms. Organization Science, 16(4), 332-343.

Davis, Gerald F., McAdam, D., Scott, W.R., \& Zald, M. N. (Eds). (2005). Social Movements and Organization Theory. Cambridge University Press.

Etzion, D. and Davis, G.F. (2008). Revolving Doors? A Network Analysis of Corporate Officers and U.S. Government Officials. Journal of Management Inquiry, $\mathrm{XX}(\mathrm{Y}), \mathrm{AAA}-\mathrm{BBB}$. 
Fukuyama, F. (1992). The End of History and the Last Man. New York. Free Press.

Greenwood, R. (2008). Focusing the Asteroid Belt of Organizations. Journal of Management Inquiry, XX(Y), AAA-BBB.

Hinings, C. R., \& Greenwood R. (2002). Disconnects and Consequences in Organization Theory. Administrative Science Quarterly, 47(3), 411-422.

Khanna, T. (2000). Business Groups and Social Welfare in Emerging Markets: Existing Evidence and Unanwered Questions'. European Economic Review, 44, 748-61.

Khanna, T. \& Yafeh, Y. (2007). Business Groups in Emerging Markets: Paragons or Parasites? Journal of Economic Literature, 45(2), 331-373.

Levy, D. L. \& Egan, D. (2003) 'A Neo-Gramscian Approach to Corporate Political Strategy: Conflict and Accommodation in the Climate Change Negotiations.' Journal of Management Studies, 40, 803-830.

Levy, D. L. \& Newell, P. (2002) Business Strategy and International Environmental Governance: Toward a Neo-Gramscian Synthesis. Global Environmental Politics, 2, 84-101.

Lindblom, C.E. (1977). Politics and Markets The World's Political-Economic Systems, New York: Basic Books.

Lipartito, K. \& Sicilia, D. B., (2004). Constructing Corporate America: History, Politics, Culture. New York: Oxford University Press. 
Lounsbury, M., Ventresca, M. J. \& Hirsch, P. M. (2003) Social Movements, Field Frames and Industry Emergence: A Cultural-Political Perspective on US Recycling. Socio-Economic Review 1: 71-104

Marquis, C. and S. Barley (2006) “Distinguished Scholar Interview”, OMT Newsletter, Fall.

Mills, C.W. (1956). The Power Elite. New York: Oxford University Press.

Mintz, B., \& Schwartz, M. (1985). The Power Structure of American Business. Chicago: The University of Chicago Press.

Mizruchi, M. S. (1992). The Structure of Corporate Political Action: Interfirm Relations and their Consequences. Cambridge: Harvard University Press.

Perrow C. (1984). Normal Accidents: Living with High-Risk Technologies. New York: Basic Books.

Perrow, C. (1986). Complex Organizations: A Critical Essay (3rd ed.). New York: Random House.

Perrow, C. (2002) Organizing America: Wealth, Power and the Origins of Corporate Capitalism. Princeton: Princeton University Press.

Reich, R. B. (2007). Supercapitalism: The Transformation of Business, Democracy, and Everyday Life. New York: Knopf.

Schneiberg, M. \& Bartley, T. (2001) Regulating American Industries: Markets, Politics, and the Institutional Determinants of Fire Insurance Regulation., American Journal of Sociology.107: 101-146 
Schneiberg, M. \& M. Lounsbury (forthcoming) Social Movements and Institutional Analysis. In R. Greenwood, C. Oliver, R. Suddaby and K. Sahlin-Andersson (eds.), Handbook of Organizational Institutionalism. Thousand Oaks, CA: Sage.

Schneiberg, M. \& S. Soule (2005). “Institutionalization as a Contested, Multilevel Process: Politics, Social Movements and Rate Regulation in American Fire Insurance,” Pp. 122-160 in Social Movements and Organizations, edited by Gerald Davis, Doug McAdam, WR Scott and Mayer Zald. Cambridge: Cambridge University Press.

Schuler, D.A. (2008). Peering in from Corporate Political Activity. Journal of Management Inquiry, XX(Y), AAA-BBB.

Stern, R. N., \& Barley, S. R. (1996). Organizations and Social Systems: Organization Theory's Neglected Mandate. Administrative Science Quarterly, 41(1), 146162.

Useem, M. (1984). The Inner Circle: Large Corporations and the Rise of Business Political Activity in the U.S. and U.K. New York: Oxford University Press.

Walsh, J.P., Weber, K. \& Margolis, J.D. (2003). Social Issues and Management: Our Lost Cause Found. Journal of Management, 29(6), 859-881. 